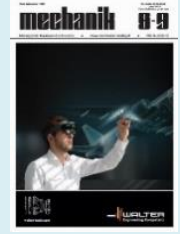

Authors: Daniel Chuchała, Kazimierz A. Orłowski

Title of article: "Prognozowanie wartości mocy skrawania dla procesu przecinania impregnowanego drewna sosnowego na pilarce taśmowej" ("Forecasting values of cutting power for the sawing proces of impregnated pine wood on band sewing machine")

\title{
Forecasting values of cutting power for the sawing process of impregnated pine wood on band sawing machine
}

\author{
Prognozowanie wartości mocy skrawania dla procesu przecinania \\ impregnowanego drewna sosnowego na pilarce taśmowej
}

\author{
DANIEL CHUCHALA \\ KAZIMIERZ A. ORŁOWSKI *
}

In this paper the predicted values of cutting power for band sawing machine (ST100R), which is used in the Polish sawmills, were presented. The values of cutting power were determined for wood of Scots pine (Pinus sylvestris L.), which was impregnated and not impregnated. These values were estimated using an innovative method of forecasting cutting forces, which takes into account the elements of fracture mechanics. The forecasts obtained in this way are compared with the values of cutting power estimated with the use of the classical method, which is based on the specific cutting resistance.

KEYWORDS: cutting power, Scots pine wood, impregnated wood, band sawing machine

By determining the energy effects of the material cutting process, one can optimally design the machine tools as well as the machining processes carried out on these machines. Among other things, this is why the determination of cutting forces - theoretical and experimental - is counted among the basic and at the same time the most advanced areas of machining mechanics [6].

The most common approach to determining cutting forces in the wood cutting process is a model based on the proper specific cutting resistance $\mathrm{kc}$ [8-10]. This model is considered classic [10] and for the most popular methods of cutting wood (using frame, band and circular saws) has according to the literature assigned other values of the proper specific cutting resistance. These values were determined experimentally $[8,10]$, but it is not known under which conditions (in the literature, this is not specified), which limits their credibility. In addition, for the saws with a narrow kerf, significant discrepancies in the values of the cutting resistance were observed [12].

In his book Atkins [3] shows that when determining the strength and cutting power, the fracture toughness of the workpiece is as important as strength or friction. Based on the Atkins theory [2, 3], which was successfully used to

\footnotetext{
* Dr inż. Daniel Chuchała (danchuch@pd.edu.pl), prof. dr hab. inż. Kazimierz A. Orłowski (korlowsk@pg.edu.pl) - Politechnika Gdańska, Wydział Mechaniczny, Katedra Technologii Maszyn i Automatyzacji Produkcji
}

describe the phenomenon in the material separation zone during the cutting of metals, wood and composite materials [3], Orłowski together with Atkins [11] proposed a model of cutting power. This model allows much more accurate forecasting of cutting power [13], taking into account the geometry of the machining tool (rake angle $\gamma_{\mathrm{f}}$ ), chip formation conditions (shear angle $\Phi_{\mathrm{c}}$ ) and properties of the material being cut, such as: fracture toughness $R_{\perp}$ (specific work needed to separate material) and shear yield stress (tangential) in shear zone $T_{\mathrm{Y} \perp}$

Investigations of wood treated with impregnation $[1,7,14]$ have shown that along with the acquisition of protective properties against fungi and weather conditions, this material changes its physical properties. Therefore, it is believed that wood impregnation can also affect the cutting forces.

The further part of the paper presents the results of forecasting cutting power when cutting Polish impregnated pine wood on a band saw. Cutting power values were determined using a model derived from modern fracture mechanics and at the same time based on the Atkins idea $[2,3]$.

\section{Test material and analyzed machine}

The material that was analyzed was pine wood (Pinus sylvestris L.) impregnated (fig. 1) and non-impregnated, coming from the same batch of sawmill material from Sylva Sp. $z$ o.o. in Wiele. For the impregnation, Korasit KS2 from Kurt Obermeier $\mathrm{GmbH} \&$ Co. KG. was used.

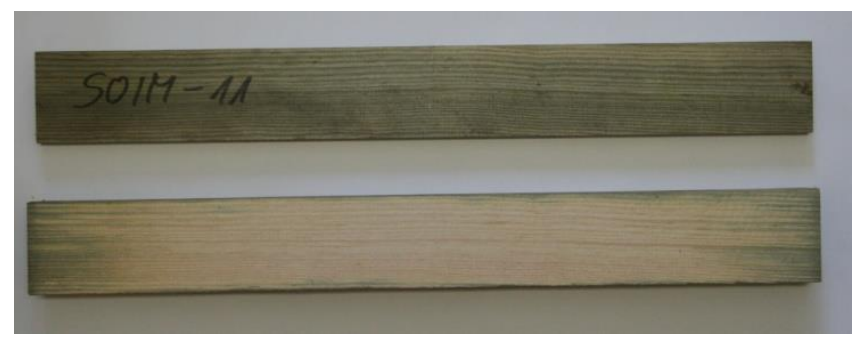

Fig. 1. Sample of impregnated pine wood (SOIM-11 sample number). An external surface is shown at the top, and the inner surface after cutting is shown below 
Material properties for the perpendicular direction of cutting speed relative to wood fibers, $R_{\perp}$ (specific energy necessary to produce a fracture with a unit surface in the course of cutting) and yield shear stress in the shear zone $T_{\mathrm{Y} \perp}$, which were used to predict cutting power values (tab. I), was determined according to the methodology developed by Orłowski and described in [11,13] using the machinability tests on a PRW15M frame saw with elliptical trajectory of blades and a hybrid, dynamically balanced drive system [15].

TABLE I. Values of toughness and shear stress in the shear zone

\begin{tabular}{|c|l|c|c|}
\hline $\begin{array}{c}\text { Desig- } \\
\text { nation }\end{array}$ & $\begin{array}{l}\text { Description of } \\
\text { material }\end{array}$ & $\begin{array}{c}\boldsymbol{R}_{\perp} \\
\mathrm{J} \cdot \mathrm{m}^{-2}\end{array}$ & $\begin{array}{c}\boldsymbol{\tau}_{\gamma \perp} \\
\mathrm{MPa}\end{array}$ \\
\hline SOIM & $\begin{array}{l}\text { Pine wood } \\
\text { impregnated }\end{array}$ & $1351,2 \pm 714,3$ & $26,26 \pm 0,488$ \\
\hline SONP & $\begin{array}{l}\text { Pine wood } \\
\text { non- } \\
\text { impregnated }\end{array}$ & $1047,5 \pm 1047,5$ & $17,24 \pm 0,92$ \\
\hline & $\begin{array}{l}\text { Significance of } \\
\text { differences } \\
\text { according to t- } \\
\text { Student's test }\end{array}$ & no & yes \\
\hline
\end{tabular}

The technological machine, for which the cutting power forecasting was performed, is a ST100R band saw from STENNER - very popular in the Polish sawmill industry. The basic parameters of the saw [16] and tools subjected to the power cutting forecasting are presented in the tab. II.

\section{TABLE II. Basic parameters of the machine and tools}

\begin{tabular}{|c|c|c|c|}
\hline$H_{P}, m m$ & 100 & $V_{f}, m \cdot \min ^{-1}\left(m \cdot s^{-1}\right)$ & $5-60(0,083-1)$ \\
\hline$n_{s b}, m m$ & 1 & $f_{z}, m m$ & $0,095-1,14$ \\
\hline$S_{t}, m m$ & 2,2 & $h, m m$ & $0,095-1,14$ \\
\hline$P, m m$ & 32 & $P_{E M}, k W$ & 15 \\
\hline$Y_{f},{ }^{\circ}$ & 20 & $P_{i}, k W$ & 2,5 \\
\hline$z,-$ & 173 & $P_{C A}, k W$ & 10 \\
\hline$v_{c}, m \cdot s^{-1}$ & 29 & & \\
\hline \multicolumn{4}{|c|}{$\begin{array}{l}\text { Designations: } H_{P}-\text { material cutting height (cutting depth, } n_{s b}- \\
\text { number of saws, } S_{t} \text { - overall set (kerf), } \mathrm{P} \text { - tooth pitch, } V_{f}-\text { rake } \\
\text { angle, } Z \text { - number of saw teeth, } V_{c}-\text { cutting speed, } V_{f} \text { - feed } \\
\text { speed, } f_{Z} \text { - feed per tooth, } h \text { - uncut chip thickness, } P_{E M} \text { - electric } \\
\text { power of the motor, } P_{i} \text { - idling power, } P_{C A} \text { - available cutting } \\
\text { power in the cutting zone }\end{array}$} \\
\hline
\end{tabular}

\section{Forecasting the cutting power}

According to the method taking into account the elements of fracture mechanics [11], the cutting power of a band saw machine is expressed as:

$\overline{\mathrm{P}}_{\mathrm{cw}}=F_{c} v_{c}+P_{\mathrm{ac}}=z_{a} \frac{T_{\gamma \perp} S_{t} y}{Q_{\text {shear }}} v_{c} \bar{h}+z_{a} \frac{R_{\perp} S_{t}}{Q_{\text {shear }}} v_{c}$

where: $F_{\mathrm{c}}$ - cutting force, $v_{\mathrm{c}}$ - cutting speed, $P_{\mathrm{ac}}$ - power needed to accelerate chips (for the band saw this member can be omitted because it takes small values [12]), average number of cutting blades in contact with kerf, St overall set (kerf), $h$ - average uncut chip thickness (for the band saw it is also the feed per blade $\left.f_{z} ; h=f_{z}\right), v$ - the shear strain along the shear plane, $Q_{\text {shear }}$ - coefficient of friction correction.

The parameter $z_{a}$ defines the formula:

$$
z_{a}=\left(\frac{H_{P}}{P}\right)
$$

where: $H_{\mathrm{P}}$ - height of the material to be cut (cutting depth), $P$ - pitch of the saw blades.

Form deformation in the shear plane is expressed by the equation:

$$
\gamma=\frac{\cos \gamma_{f}}{\cos \left(\Phi_{c}-\gamma_{f}\right) \sin \Phi_{c}}
$$

where: $\gamma_{f}$ - rake angle, $\Phi_{c}$ - shear angle, which determines the position of the shear plane with respect to the cutting surface.

The coefficient of friction correction is equal to:

$$
Q_{\text {shear }}=\left[1-\left(\sin \beta_{\mu} \sin \Phi_{c} / \cos \left(\beta_{\mu}-\gamma_{f}\right) \cos \left(\Phi_{c}-\gamma_{f}\right)\right)\right]
$$

where: $\beta_{\mu}$ - friction angle, referred to as $\beta_{\mu}=\tan ^{-1} \mu$, where $m$ is the coefficient of friction between the rake face and the chip and is $\mu=0.6$ [5].

The shear angle $\Phi_{\mathrm{c}}$ is defined by the following equation, which is solved by means of numerical methods [3]:

$$
\begin{aligned}
& {\left[1-\frac{\sin \beta_{\mu} \sin \Phi_{c}}{\cos \left(\beta_{\mu}-\gamma_{f}\right) \cdot \cos \left(\Phi_{c}-\gamma_{f}\right)}\right] \cdot} \\
& \cdot\left[\frac{1}{\cos ^{2}\left(\Phi_{c}-\gamma_{f}\right)}-\frac{1}{\sin ^{2} \Phi_{c}}\right]= \\
& =-\left[\cot \Phi_{c}+\tan \left(\Phi_{c}-\gamma_{f}\right)+Z\right] . \\
& \cdot\left[\frac{\sin \beta_{\mu}}{\cos \left(\beta_{\mu}-\gamma_{f}\right)}\left\{\frac{\cos \Phi_{c}}{\cos \left(\Phi_{c}-\gamma_{f}\right)}+\frac{\sin \Phi_{c} \sin \left(\Phi_{c}-\gamma_{f}\right)}{\cos ^{2}\left(\Phi_{c}-\gamma_{f}\right)}\right\}\right]
\end{aligned}
$$

where: $Z$ - parameter that takes into account the effect of the material type on the shear angle $\Phi_{c}$ and is given by the formula:

$$
Z=\frac{R_{\perp}}{\tau_{\gamma_{\perp}} \cdot f_{z}}
$$

For comparison purposes, the cutting power values were also determined using the classic approach [8], based on the appropriate specific cutting resistance $k_{\mathrm{c}}\left(\mathrm{kc} \_\right.$Man):

$$
P_{c}=\frac{v_{f} \cdot S_{t} \cdot H_{P}}{60} k_{c}
$$

Values of the proper specific cutting resistance were calculated using the relationship proposed in the book [8], suitable for the case of cutting pine timber on a band saw:

$$
k_{c}=9,91\left(5,3+0,01 H_{p}-0,03 v_{f}\right)
$$

where $H_{\mathrm{P}}$ is expressed in $\mathrm{mm}$, and $v_{\mathrm{f}}-$ in $\mathrm{m} \cdot \mathrm{min}^{-1}$.

The values obtained from equation (8) were multiplied by a factor of $k_{v c}=1.04$ [8, 10], which takes into account the cutting speed. 


\section{Cutting power forecasting results}

The forecasted values of cutting power for the cutting process on a band sawing machine of impregnated and non-impregnated pine wood are shown in fig. 2 . They were obtained from forecasts carried out using two methods:

- classical method, based on the appropriate specific cutting resistance ( $\mathrm{kc} \_$Man)

- method that takes into account elements of fracture mechanics (Atkins idea).

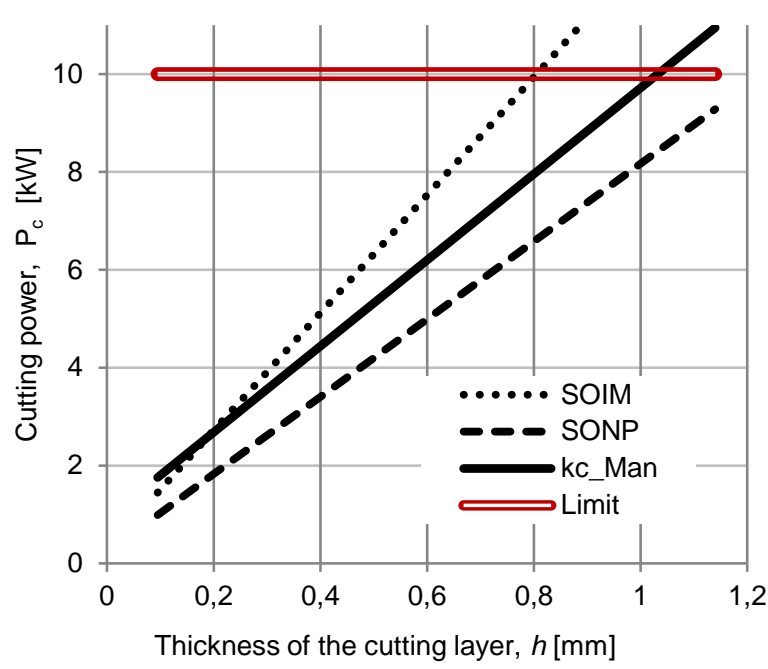

Fig. 2. Determined values of cutting power for pine wood cutting process (SOIM - impregnated, SONP - non-impregnated) on the ST100R band saw from STENNER

Differences between the cutting power values for impregnated and non-impregnated wood are noticeable. The cutting power values for wood impregnated already at the uncut chip thickness $h=0.8 \mathrm{~mm}$ reach the power limit of the main drive motor (Limit) and are $50 \%$ higher than the cutting power value for unprocessed wood. In the case of non-impregnated wood, it is possible to cut the material in the full available range of the uncut chip thickness $h$. The forecasted power based on literature data (kc_Man) deviates from the analyzed cases, which may be caused by the influence of wood origin on cutting power values [4].

\section{Conclusions}

The method of forecasting the energy effects of the cutting process on the band saw, including the elements of fracture mechanics, allows for a more accurate determination of the cutting power value and taking into account whether the wood has been impregnated.

In the case of pine wood (Pinus sylvestris L.) impregnated, there is a greater energy demand for the sawing process on band saws.

\section{Acknowledgments}

The authors would like to thank Piotr Tube from the company Sylva Sp. z o.o. in Wiele (Poland) for providing pine wood used in the presented research.

\section{REFERENCES}

1. Adamur H., Fidan M.S., Yasar S.S. "The technological properties of oriental beech (Fagus orientalis Lipsky) impregnated with boron compounds and natural materials". BioResources. 12, 1 (2017): pp. 1647-1661.

2. Atkins A.G. "Modelling metal cutting using modern ductile fracture mechanics: quantitative explanations for some longstand- ing problems". International Journal of Mechanical Sciences. 45 (2003): pp. 373-396.

3. Atkins A.G. "The science and engineering of cutting. The mechanics and process of separating, scratching and puncturing biomaterials, metals and non-metals". Oxford: ButterworthHeinemann is an imprint of Elsevier, 2009.

4. Chuchala D., Orlowski K., Sandak A., Sandak J., Pauliny D., Baranski J. "The effect of wood provenance and density on cutting forces while sawing Scots pine (Pinus sylvestris L.)". BioResources. 9, 3 (2014): pp. 5349-5361.

5. Glass S.V., Zelinka S.L. "Wood Handbook - Wood as an Engineering Material (Centennial Edition). (Chapter 4: Moisture Relations and Physical Properties of Wood)". Madison. General Technical Report FPL-GTR-190. WI: U.S. Department of Agriculture, Forest Service, Forest Products Laboratory, 2010, s. 508, www.fpl.fs.fed.us/documnts/fplgtr/fpl gtr190.pdf

6. Grzesik W.. „Podstawy skrawania materiałów konstrukcyjnych”. WNT, 2010.

7. Konopka A., Baranski J., Orlowski K., Szymanowski K. "The effect of full-cell impregnation of pine wood (Pinus sylvestris L.) on changes in electrical resistance and the accuracy of moisture content measurement using resistance meters". BioResources. 13, 3 (2018): pp. 1360-1371.

8. Manžos F.M. "Derevorežuŝie Stanki". Moskva: Izdatel'stvo Lesnaâ Promyšlennost', 1974.

9. Naylor A., Hackney P., Perera N., Clahr E. "A predictive model for the cutting force in woodmachining developed using mechanical properties". BioResources. 7, 3 (2012): s. 2883-2894.

10. Orlicz T. "Obróbka drewna narzędziami tnącymi". Warszawa: Wydawnictwo SGGW-AR, 1983.

11. Orlowski K.A., Atkins A. "Determination of the cutting power of the sawing process using both preliminary sawing data and modern fracture mechanics". In: Navi P., Guidoum A. (eds): Proceedings of the third international symposium on wood machining. Fracture mechanics and micromechanics of wood and wood composites with regard to wood machining. 21-23 May, Lausanne, Switzerland: Presses Polytechniques et Universitaires Romandes, 2007.

12. Orlowski K.A. "The fundamentals of narrow-kerf sawing: the mechanics and quality of cutting". Publishing House of the Technical University in Zvolen, Technical University in Zvolen, 2010.

13. Orlowski K.A., Ochrymiuk T., Atkins A., Chuchala D. "Application of fracture mechanics for energetic effects predictions while wood sawing". Wood Science and Technology. 47, 5 (2013): pp. 949-963 (open access).

14. Percin O., Sofuoglu S.D., Uzun O. "Effect of boron impregnation and heat treatment on some mechanical properties of oak (Quercus petraea Liebl.) wood". BioResources. 10, 3 (2015): pp. 3963-3978.

15. Wasielewski R., Orlowski K. "Hybrid dynamically balanced saw frame drive". Holz Roh-Werkst. 60 (2002): pp. 202-206.

16. STENNER. ST100R Radial Arm Resaw, Stenner Ltd. (pdf, ulotka), 2011.

Translation of scientific articles, their computer composition and publishing them on the website www.mechanik.media.pl by original articles in Polish is a task financed from the funds of the Ministry of Science and Higher Education designated for dissemination of science.

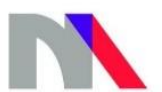

Ministry of Science and Higher Education 